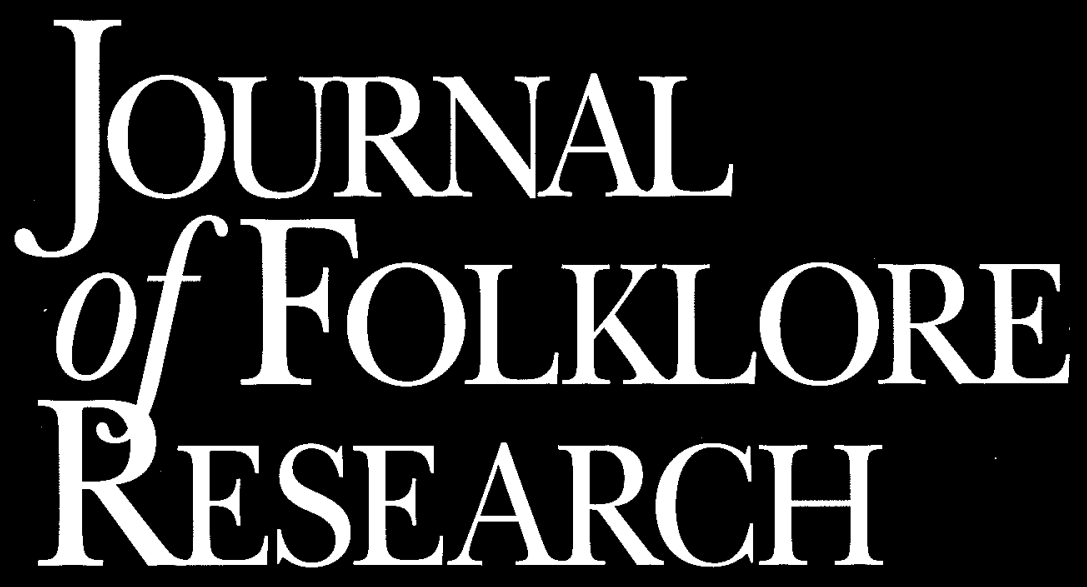

Volume 39, Numbers 2/3

May-December 2002
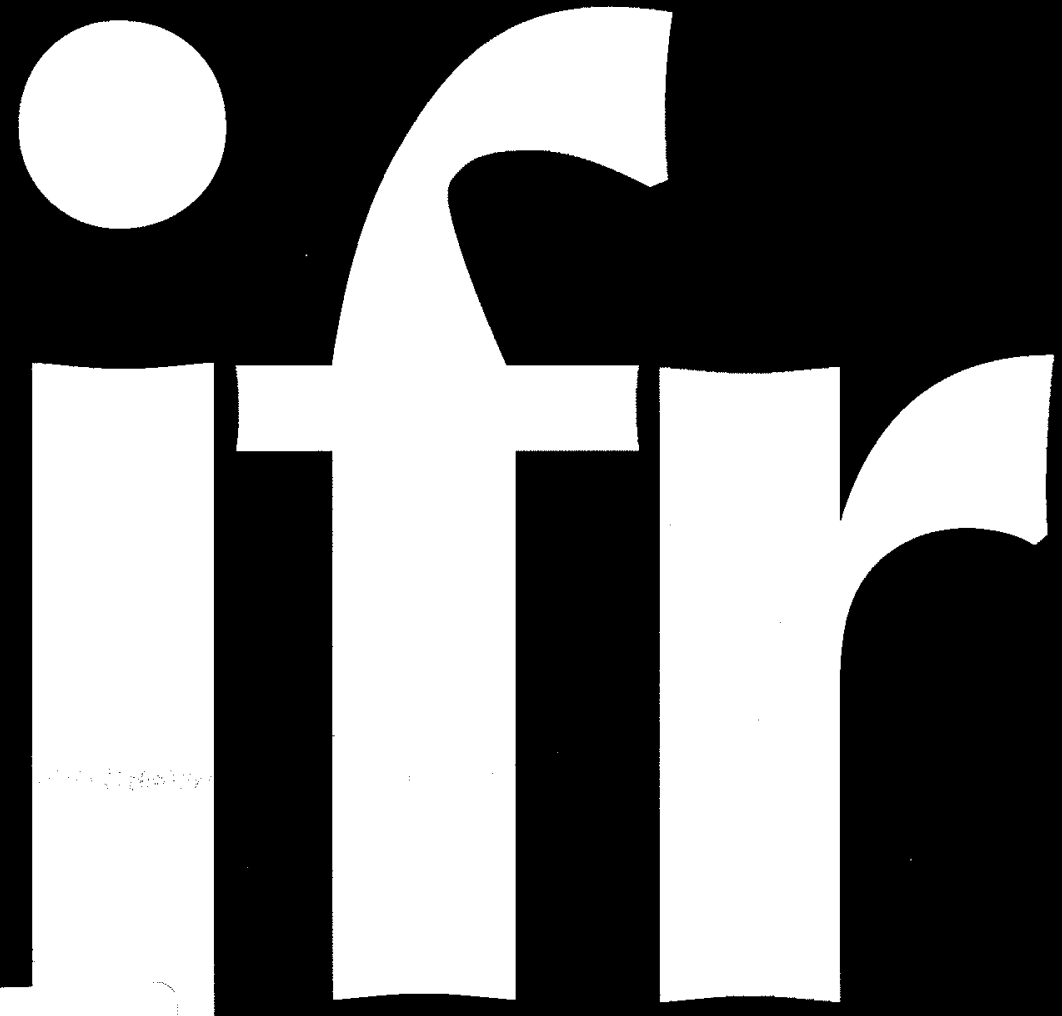
1 'ha Journul of Folklore Research (ISSN 0737-7037) is edited at the Indiana Universily liolklore Institute and published three times a year by Indiana University l'ress, which assumes no responsibility for statements expressed by the authors. Subscription rates, in U.S. funds, are: institutions, $\$ 50.00$; individuals, $\$ 27.50$; studcuts, $\$ 22.50$ (orders must be accompanied with a copy of a valid ID). Postage strchatge outside of the USA is $\$ 10.00$ per volume for surface mail, $\$ 21.00$ per volume for air mail. Single issues are $\$ 13.25$ each, except for those with a special (opic, which are $\$ 16.95$ each, or double issues, which are $\$ 18.95$ each. Add $\$ 4.00$ for the first single issue ordered and $\$ 1.00$ for each additional. A discount is aviliable on bulk orders for classroom use or bookstore sales.

No pall of this publication may be reproduced, stored in a retrieval system, or 11:11smitted in any form by any means, electronic, mechanical, photocopying, or ulicrwisc, without the prior permission of the publisher. For educational reprinting, please contact the Copyright Clearance Center (508-744-3350). For :Ill other permissions, please visit http://iupress.indiana.edu/rights.

Arlliess all subscriptions and business correspondence to the Journals Division, I dilina University Press, 601 North Morton Street, Bloomington, Indiana 47404$\$ 797$ USA; e-mail: journals@indiana.edu; URL: http://iupjoumals.org. Notice of ninicceipt of an issue must be sent within four weeks after the receipt of the subsequent issue. Please notify the Press of any change of address. Issues missed bcciutse of out-of-date addresses will not be re-placed. Manuscripts and other clitorial correspondence should be addressed to the Editors, the Journal of folktow Research, Indiana University Folklore Institute, 504 North Fess Avenue, Hoomington, Indiana 47405 USA.

(IST: R126496330

POSTMASTER: Send address change to the Journal of Folklore Research, JourInits Division, Indiana University Press, 601 North Morton Street, Bloomington, Indiana 47404-3797. 


\section{Silences across Disciplines: Folklore Studies, Cultural Studies, and History}

IN THIS ESSAY, which is based upon a paper we gave at the Seventh SIEF Conference in Budapest in April 2001, we present some results of an ongoing dialogue between the two of us over the past years. A recent focus of our discussions has been the relations between Folklore Studies, Social History, and Cultural Studies. More generally, we have ranged across questions concerning our own positions in the academic field and the production of knowledge and power inside and outside the academy. "The academy" is a rather abstract notion in this instance, since "our" academies are very differently located, and we in them.

\section{Barbara Henkes (born 1955)}

As a student in modern history at the Dutch University of Groningen during the ' $70 \mathrm{~s}$, I was active in the students' movement, particularly in discussions concerning curricular reform. We asked for more attention to social (labor) history, women's history, and what we called "emancipating history" in general. At the time a group of us regularly crossed the English Channel in order to visit History Workshop gatherings, where in 1979 I was present during a heated public debate between Stuart Hall, Edward Thompson, and Richard Johnson about history and theory. ${ }^{1}$ After finishing my studies, I worked for ten years as a freelance journalist/historian more or less outside the academy, though I was an active member of the board of the Dutch Oral History Society and the history group of the Communist Party 
of the Netherlands (CPN). Later I got grants for research projects at different Dutch universities; most recently, I work as an historian connected to the Meertens Institute, which houses the main research center for Folklore Studies (Dutch Ethnology) in the Netherlands.

My early research focused on the social history of excluded and marginalized groups, a typical emphasis of Social History at that time. I finished my studies with a project on criminality and unemployment in the city of Groningen during the 1930s (Henkes 1980). The unexpected discovery of information about women domestic servants in city police records coincided with the emergence of women's history and led to my study of how these women used the limited space available to them to shape their ways of working and living (in). ${ }^{2}$ The identifications and disidentifications that the women made with the places and people of their new surroundings proved to be primary notions in my understanding of the specific position of domestic servants within bourgeois households in those days. In addition to investigating documents on "the maid-servant problem" from the mistresses' vantage points, I also talked to former housemaids in order to analyze their positions and coping strategies. This was the beginning of a continuing interest in individual life stories as a way of understanding larger social and cultural conditions while keeping questions of agency-individual and collective-in the forefront of my research.

From there, I became intrigued by the migration of tens of thousands of German maids to the Netherlands during the inter-war period. Thus, in my doctoral research I broadened my focus from Dutch households to Dutch society more generally, especially in times of economic and political crisis. ${ }^{3}$ Again, a biographical approach proved a valuable way to learn more about migration and the formation of national (Dutch and German or Dutch-German) identities in relation to the rise of national socialism and the German invasion of the Netherlands.

It was because of my interest in the making and unmaking of national identities that I made two shifts in the orientation of my research. In 1998, I was appointed by the Meertens Institute to write a history of the social and political engagements of Folklore Studies in the Netherlands between 1920 and 1950. This new position involved my looking at more articulated forms of culture in the shape of specific traditions of knowledge. In addition, the task required me to look at a group that was not dominant (indeed, was rather marginal) in relation to the academy, but nevertheless had plenty to say for itself, often in elaborated and written forms. A biographical approach has helped me to understand how the (mainly) males who participated in this particular discipline shaped it into a distinctive intellectual politics and how cultural politics (varying in kind from democratic to national socialist) shaped their intellectual practices and social lives (e.g., Henkes 2000; Johnson 2000).

\section{Richard Johnson (born 1939)}

I also began my academic life as an historian, though in the very different context of early 1960s Cambridge, then a home to conservative historiography. The debates around E. H. Carr's What Is History (1964) had only just begun as I graduated. After completing my Ph.D., which was on education and the state in Britain from the 1830 s to the 1870 s, I discovered another kind of history through the British Marxist historians, especially E. P. Thompson (Thompson 1963). From 1966 I taught social history at the University of Birmingham, where the students' movements of the late ' 60 s and early ' 70 s made me aware of relations of power and knowledge and the impossibility of splitting scholarship and politics. My research at that time-a rethinking of my Ph.D. - was on the growth of mass schooling as a site of cultural conflict, especially around class (Johnson 1970, 1976).

From the mid 1970s I was attracted to contemporary history as a way of connecting my politics and my teaching and research. I changed academic departments at Birmingham, from Economic and Social History to the Centre for Contemporary Cultural Studies (CCCS), founded in 1964. I remember receiving advice from all concerned not to change to such a "risky" area. In what I still thought of as historical work, my interest shifted to analysis of changes in contemporary educational policy in the 1970 s and 1980 s, which saw the beginning of neo-liberal restructuring in Britain (CCCS Education Group 1981). For similar reasons I turned from studying the past to examining how the past was represented in the present: in historiography, in nationalist discourse, in deliberate representations of "heritage," and in popular memory (CCCS 1982). The CCCS, initially mainly a research center, was strongly committed to innovative pedagogies, including group work, co-research between teachers and 
students, self publication, and making connections with emergent social movements (Johnson 1997).

By the mid 1990s, when I left Birmingham for the new University of Nottingham-Trent, it was clear that in one form or another, everyone now was studying the cultural. So what was distinctive about Cultural Studies, which had pioneered many lines of research, in the new context? While continuing work on my old themes as well as some new ones (theories of sexuality and the production of sexual identity in schools and in the media) (Epstein and Johnson 1998), I grew increasingly interested in interdisciplinary relations in this larger field of culture study. This included a return to relations between Cultural Studies and history that had been a key theme in debates on theory from the ate 1970s. It also involved engagements with other cultural disciplines especially Folklore Studies and Cultural Geography.

Throughout the $1990 \mathrm{~s}$, Barbara and I had been talking about similar themes in relation to Cultural Studies and Social History. So when she took the job at the Meertens Institute, our interests in Folklore Studies coincided and our long-term interests in the academy as a national/international field of knowledge and in the role of intellectuals found a sharper empirical focus.

\section{$B H$}

Folklore Studies? Faces turned blank when I mentioned the discipline. And to be honest: before I started working at the Meertens Institute, I had not come across Folklore Studies myself. Only since then have I become familiar with the knowledge and perspective developed in this field. I was astonished. Why had this discipline never caught my attention? It had so much common ground with the kind of history that interested me; yet those involved in labor history, women's and gender history, oral history, and other forms of post war social history had seldom crossed the paths of the folklorists.

In an odd way, my own restricted bibliographical searches paralleled the isolation of Folklore Studies in the Netherlands, which has been more or less contained to the Meertens Institute in Amsterdam (see Dekker 2000:62), a research institute outside the university. This structural separation has encouraged a rather withdrawn attitude, one that is so well (and painfully) described by the retired head of the Folklore Studies department, Han Voskuil. In a series of romans à clef known as The Bureau, Voskuil presents a literary version of life among folklorists based on his everyday "fieldwork" in the national and international arena of Folklore Studies (1996-2000). Still, the silences between a critical Social History and Folklore Studies cannot be explained merely by pointing to the relative isolation (until recently) of the Meertens Institute; there has to be more to it. Exchanges with Richard Johnson strengthened this impression.

\section{$R J$}

My interest in Folklore comes from two aspects of the history of academic disciplines: first, the significance of national differences in the organization of the "cultural" disciplines; second, the "transdisciplinarity" of culture study just now-the crossing of so many borderlines and the creation of patterns of competition, exchange, and silence.

My story about Folklore Studies is similar to Barbara's. When I was at the CCCS in Birmingham, we had fruitful contacts with Empirical Cultural Studies in Tübingen and then with European Ethnology at the Humboldt University in Berlin. I have taught "short courses" at both institutes. They knew more about our work-or some parts of it-than we knew of their traditions and current work. I also remember an interesting but confusing visit to the University College at Cork, Ireland, where there were plans to set up a center for the study of culture. I realize now that this visit confused me because Folklore Studies did not figure at all in the version of culture study developed at Birmingham, but was a major component in the Irish version. Similarly, Folklore Studies is a presence in many if not most European countries. In different national traditions, it has different degrees of prominence and variant relations within and without the academy.

The two disciplinary formations overlap, especially at that point where Cultural Studies is (to use our preferred term) at its most "ethnographic." Yet there's been no systematic or sustained dialogue between Cultural Studies and Folklore Studies in England. Folklore Studies does not figure in the interdisciplinary clusters within which Gultural Studies is taught, nor is the field acknowledged in the historiography of Cultural Studies. I am probably the first Cultural Studies scholar to be interested in what Richard Dorson (significantly, a U.S. folklorist) called "the Great Team" of English folklorists who helped 
found the discipline in the late nineteenth and early twentieth centuries (Dorson 1968). The founding stories of Cultural Studies begin with the post-war New Left and with literary criticism, Social History, and a new interest in modern media and popular consumption in the long boom of the 1950s (e.g., Storey 1996). I too get blank faces when I refer to Folklore Studies-as I do nowadays when discussing our need for international cross-disciplinary exchanges.

\section{$B H$}

In our essay we look for an explanation for the disassociation of Folklore Studies, Social History, and Cultural Studies in our different but linked national contexts. Is it due to diverse political engagements, to disciplinary traditions, and to (inter) national differences? And what can be gained-or might be lost-by crossing the boundaries?

\section{$R J$}

Of course, we know these silences have not been absolute. In the Netherlands the voices of historians like William Frijhoff, Herman Roodenburg, and Gerard Rooijakkers were heard in the field of Social History as well as in that of Folklore Studies, but their contributions were mainly about pre-modern times. ${ }^{4}$ As historians approach modern, industrialized society, exchanges with Folklore Studies seem blocked. There are also English exceptions, again primarily in premodern work, more rarely after. Edward P. Thompson, for example, was in sustained dialogue with folklorists. He wrote for Folklore (the journal of the English Folklore Society) and was handsomely memorialized in its pages when he died. ${ }^{5}$ He was fascinated by custom and ritual and by popular practices like Rough Music; his historical sources included the early English folklorists and antiquarians. Significantly, his relation to the academy was always rather ambivalent. He was critical especially of tendencies toward "the Business University" and the inability of what he called "Academicus Superciliosis" to see beyond the next meeting and "crafty calculation of short-term advantages" (Thompson 1970:153).

In view of Thompson's fascination with folklore and his centrality in modern Social History, it is surprising that Folklore Studies did not play a larger role in gatherings of the History Workshop Movement.
The folksong revival of the 1970 s was part of the political culture from which the History Workshops arose. Early participants remember "all the singing" (Davin 2000:240). The History Workshop Journal carried interesting articles by Alun Howkins and others on English folksong, the folksong collectors, and the folksong revival (e.g., Armstrong and Pearson 1979; Howkins and Dyck 1987). Peter Burke's discussion of popular culture and the eighteenth- and nineteenthcentury nationalist intellectuals in one workshop did throw light, incidentally, on the origins of Folklore Studies (Burke 1981).

The work of Raphael Samuel, a key organizer of the movement and a tutor in adult education at the college for trade unionists (Ruskin College at Oxford), shows recurrent engagements with folklore. Later, he was fascinated by popular memory and "heritage," the term now used in British debates to encompass museums and all forms of historical representation for non-academic publics (Samuel 1994). Unlike Pierre Nora in France, however, Samuel studied popular historical enthusiasms: heritage from below, if you like. Arguing with Cultural Studies while drawing on it, he touched on issues parallel to those of the U.S./German debates on "public folklore" articulated in this journal in $1999 .{ }^{6}$ He always wrote, however, as an historian. As Luisa Passerini has argued, his Theatres of Memory was part of a bigger convergence between history and "culturality," in which historical representation itself is viewed as a cultural practice (Passerini, Friedenson, and Niethammer 1998). Significantly-for a cultural activist of his kind-Samuel (like Thompson) was half inside and half outside the academy. He highlighted the cultural significance of many popular practices that were often regarded as trivial, irrelevant, and hopelessly "conservative." He organized and enabled many popular historical projects, linking adult education, popular history, and the more political of his academic colleagues.

\section{$B H$}

In the early seventies, when I started to study history, my bookshelves were slowly but steadily filled with books from the Socialistische Uitgeverij Nijmegen (Socialist Publishers Nijmegen) which—by the way-reoriented toward cultural history after 1985, changing its name accordingly to the SUN publishing house. Besides reprints of classics from the early twentieth century, such as Capital and Labour by the 
communist Henriëtte Roland Holst, my shelves contained the Dutch Yearbooks of Socialism and the Labour Movement ${ }^{7}$ and the Dutch Journal of Social History, side by side with Friedrich Engels's The Conditions of the Working Class in England (with an introduction by Eric Hobsbawm), E. P. Thompson's The Making of the English Working Class, and the His tory Workshop Journal. Throughout the eighties, I added the Dutch Yearbooks of Women's History, as well as publications of the CCCS in Birmingham and oral historians like the Dutch Selma Leydesdorff, the German Lutz Niethammer, the Italian Luisa Passerini, and the Englishman Paul Thompson.

This partial inventory of my bookshelves indicates an Anglo-Saxon Marxist-feminist orientation and a primary interest in modern, industrialized societies. Not surprisingly, I found quite a few of these books on Richard's bookshelves, too. During the seventies research into the organized struggle against capitalism and patriarchy stood high on the agenda, motivated by an urge to "learn" from the past for the benefit of the present and future. It was the time of "actionresearch" and questions about how historical research could be of any use for the "liberation of labor" and the liberation from patriarchy, from heterosexual domination, or from racist and other oppressive structures. ${ }^{9}$

With this explicit political positioning, the critical social historians wanted to show and discuss the power relations involved in historical research and question the complex relations between politics and the academy generally. The topics of history-writing should not be limited to political institutions or economic development: that just confirmed the dominant relationships as "historically evolved." Moreover, we got bored by histories that (re)presented mainly "leading men" as past actors. We looked for other approaches that made visible dissonant voices, marginalized groups, contrary strands, and unknown perspectives. In the terms of the $1970 \mathrm{~s}$, it was "people's history," "history from below," or Alltagsgeschichte that deserved attention.

Couldn't this have been a moment when social historians and folklorists-both with a version of people's history-found each other? Perhaps, but they didn't. Why not? While historians of the popular in the Netherlands were becoming (romantically, perhaps) politically engaged, folklorists were busy "freeing" themselves from their romantic and politically engaged past in which ideas of the popular as "the folk" had dominated the field. While a student protest generation was criticizing so-called "objective" academic practices, Folklore Studies in the Netherlands (in contrast to some places in Germany) was retreating into a niche far from the struggles in the universities, seeking to develop the discipline on the (un)political sidelines.

Not that the head of Dutch folklore research believed in an "objective" academic practice. Voskuil's articles show his awareness of the impossibility of an objective, neutral science. ${ }^{10}$ Yet he still wanted to build a dam against the cultural and political interventions that had marked the discipline for so long, especially during national socialist occupation. Defensively, folklore scholars entrenched themselves in an ivory tower, just as a new generation of politically engaged historians, anthropologists, and students in Cultural Studies wanted to break its walls down.

Voskuil, like his American colleague Richard Dorson, wanted to keep politics and "dilettantism" at a distance and made a strict division between academic folklore and "folklorism" (e.g., Dekker 2000:64; Kirshenblatt-Gimblett 1988). Dorson's condemnation of all ideological applications was related to Cold War antagonisms and to communist strategies of cultural intervention. Voskuil too feared 1970s left-wing pressures, but in his case it was the Nazi legacy that made him so sensitive to political interventions in the discipline. He seems also to have resisted the romanticized and essentialist notions that could be involved in research into "the common people"-sometimes for good reasons. Yet, instead of entering the debate, he and his fellow Dutch folklorists withdrew.

Even without such a dialogue, the concepts of a critical Social History and its identifications with subjugated groups and their collective protests were soon questioned. In the eighties, the dichotomies between poor/rich, labor/capital, women/men, blacks/ whites, and resistance/domination were found to be too simple. Feminists criticized Marxist conceptions and shifted their focus from women studies to gender studies (e.g., Scott 1988). There were the Black Studies critiques and reassessments of imperial pasts. Histories limited to oppressed groups and their collective protests were questioned. Oral historians, focusing on memory and life histories, entered into transdisciplinary debates on identifications and representations at international oral history conferences with social historians, cultural anthropologists, and scholars of literature 
(e.g., Samuel and Thompson 1990). The fixed oppositions of the powerful/powerless or the haves/have-nots were no longer an adequate framework for exploring the coexistence of different conflicts, the internalization of social identities, and the disciplining and marginalizing of subordinate social groups.

Three newer concerns emerged in European culture studies at the beginning of the eighties. There was a growing interest in the biographical, in the continuities and discontinuities of individual life stories. As perspectives widened to relationships of power and difference within larger social and cultural formations, scholarly attention shifted from the social towards the cultural, including questions about personal and collective identifications and the relationship between agency and hegemonic structures. Scholars in Cultural Studies and Social History intensely debated theory, epistemology, and orientations to past or future, even while they shared similar concerns in practice (e.g., hegemony and counter-hegemony). They linked the larger symbolic field to new topics like material culture-household possessions, religious practices, clothing, and eating. Such topics again cut across the disciplines and could have brought about a stronger interest in the work of the folklorists.

\section{$R J$}

Cultural Studies began to combine studies of group life and local cultural milieus with critical explorations of contemporary public cultures: media forms, political discourses, scientific knowledge. We had to understand powerful public narratives in order to grasp the pressures on subordinated groups. Yes, groups and individuals made up their own stories-but under cultural and material conditions that they did not choose. The widening of cultural analysis-from the ways of life or struggle of particular social groups to the movements of the cultural formation as a whole, for example from the position and experiences of women to the workings of the gender order-involved a fuller engagement with social and cultural theories. For the more theoretically minded (including myself), this involved going back to Marxism to find non-reductive ways to explore the role of culture. We often found useful tools in the work of "cultural Marxists" (including the Marxist historians) associated with the Western Communist parties. As critics from within or without, they were preoccupied with the moral, cultural, or ideological aspects of struggles (e.g., Hall 1981; Johnson 1981). Later, Cultural Studies scholars borrowed from post-structuralist theory in order to understand the movements of what Foucault called "discursive formations," those not only of knowledge and meaning but also of power, discipline, and resistance (Foucault 1980).

Initially, "cultural formations" were approached as implicitly framed by the nation state. But in the 1980s the issue of nationalism came to the fore again, as an issue and a problem. More specifically, attention focused on the articulations of nation, ethnicity, and "race." National identity was also rethought as a strongly gendered process involving the constitution of gender differences and of sexual identities. Globalization and moves towards European unity, together with the ending of Communism and the Cold War, both unsettled and revived the national question and reorganized international relations. The longer-term impacts of post-war migration and settlementoften from ex-colonial countries to the old imperial metropolisesundermined the whole conception (never very real) of the nation as an essentially homogeneous entity. In Britain, black intellectuals involved in Cultural Studies (whose work fairly soon was introduced in the Netherlands) played a leading role in questioning these hidden assumptions of white ethnicity (e.g., Gilroy 1987; Hall et al. 1978; see also Morley and Chen 1996). Scholars also increasingly recognized how gender relations and sexual questions were ways of policing national and ethnic boundaries (see Lutz, Phoenix, and Yuval-Davis 1995; Yuval-Davis and Anthias 1989).

Perhaps two intellectual developments provided tools for rethinking social identities generally. First, a wave of anti-essentialist argument spread across the humanities and social sciences, allowing further reflection about the multiplicity and combinations of identities and cultural belonging. Second, a growing interest in the spatial dimensions of power, social relations, and identity emerged, especially through the innovation of cultural geography (e.g., Lowenthal 1985). By the 1990s, going beyond the white nation and its territorial boundaries, or seeing it in its postcolonial relations, became a leading theme of critical Social History and contemporary Cultural Studies (e.g., Chambers and Curti 1996). Sensitivity to the persistent racialization of minorities (and majorities) and to the positive aspects of multi-ethnicity and its new cultural identities affected key cultural categories. 
II is no longer appropriate, if it ever was, to see cultures as relaively homogeneous and settled ways of living within definite territotial boundaries. In the hands and lives of human agents, cultural elements travel and merge. It is important to remember that neither Social History nor Cultural Studies has been exempt from the historical connection with ethnicized nationalism that has so often haunted Folklore Studies. Perhaps we can all learn from the different histories in order to go beyond ethnic or nationalist limits. The connections between nationalism and racial and ethnic identities are today, for instance, played out within "heritage": public representations of the past, from the world of museum work to commercially organized visitor sites at places of historical interest (Hall 1999-2000). Along with gender and class, "heritage" is a very significant area of intervention for critical intellectuals today.

In explaining the disassociation between Cultural Studies and Folklore Studies, I agree with Barbara's stress on political starting points. The concern with culture, power, and identity also came out of a socialist inheritance and the radical social movements beginning in the 1960s. Cultural Studies has been a (sometimes quarrelsome) sister movement to the "histories from below," and the disciplines share the same complicated political parentage. Our disciplinary histories, our myths of origin, are sometimes rather too insistent about these connections to movements for social justice, and few have explored the links between nationalism, imperialism, and the study of popular cultures in the late nineteenth century (in the form of Folklore Studies and Anthropology, for instance). Those of us who had a hand in establishing Cultural Studies in the academy worked with a foreshortened historical perspective. Taking the story back to the 1880 s would be self-revealing and would help us to understand the disconnections among the disciplines we are exploring here.

In addition to political differences, we must consider elements of timing, national traditions, and histories of the academy. Folklore Studies had a heyday in England during the period before World War I (Dorson 1965, 1968; Newall 1971). Analysis of its subsequent decline might center not only on the social history of the pre-war theorists, but also on the rank and file participants in folklore festivals, performances, and collection in the inter-war decades. Was there a particular social mix of relatively leisured groups involved in folklore whose social conditions had changed by the end of World War II? What part did changing patterns of work, leisure, and domestic service (a major provider of leisure time for middle-class men and women) play in this process? The fortunes of colonial empires, and therefore the making and breaking of connections between imperial collectors and the anthropological and folklore theorists in the imperial metropolis, are another important dimension in the Dutch and English cases. What seems clear is that the interest in folklore in England, though not in Scotland, Wales, or Ireland, was in relative decline through the inter-war years, only to be revived again (often in association with Left Wing politics and an anti-nationalism) in the new conditions of the 1960s and 1970s.

The growth and the decline of Folklore Studies as a cross-class, extra-academic intellectual enthusiasm predated the post-war growth of the contemporary academy, and in the Netherlands as in England, Folklore Studies failed to gain an academic foothold or much official recognition. Cultural Studies, by contrast, developed as public education was being democratized. Its growth in Britain was associated with adult education in the 1950s, with progressive curriculum reform in the schools, and with university expansion in the 1970s and 1980s (Steele 1997). It became one of the new, usually "interdisciplinary" subjects that provided the momentum for curriculum development in the university sector, especially in the polytechnics, which became the new universities. Although Social History drew on a much longer association with the universities (but also on extensive extraacademic networks), it too found an accepted place in the academy. It too became a radicalized subject, linked to strong currents outside the academy, to which successive generations of radically minded students were attracted or through which they were radicalized.

These developments are quite intimately expressed in my own academic life. As a teacher of Social History (formally from 1966 to 1974) my sense of new demands on myself and my subject area was very strong. It is not surprising, perhaps, that I ended up teaching Cultural Studies. As a practice of education and research, Cultural Studies was based on the idea that the learning process began with the agenda of interest stemming from students' lives. Cultural Studies institutionalized this responsiveness in its forms of pedagogy and curriculum. 
So while Folklore Studies in England remained extra-academic and somewhat cut off from critical academic discussions, Cultural Studies and the new Social History became link points between the expanding academy and the social movements of the day. It is unlikely that exactly this pattern will fit other national histories, not least because of differences in academic traditions and the ways they have changed-or not-from the pre-war years. But this account does bring to view the importance of histories of the academy as an institution for understanding differences and silences between disciplines. It is clear, for instance, that the effects of the institutionalization of knowledge within the academy may cut both ways, providing the means for the development and reproduction of critical intellectual currents as well as divorcing them from their points of genesis in popular movements.

The period from 1990 onward is often seen in terms of the depoliticization of academic disciplines. Postmodernist thinking and the awareness of ever-changing and overlapping positions and perspectives meant the end of a straightforward "identity politics." We welcome this development insofar as it helps us think about the extreme complexity of political struggles. We are cautious about it to the extent that it allows political issues to be evaded altogether-a not unheard-of tendency among academics. We also want to stress a different aspect. Ongoing debates about the nature of knowledge as "situated" and "partial" (Foucault 1980; Haraway 1991) and about the responsibilities and accountability of academics bring political issues, new and old, close to our own (academic?) homes. Simultaneously, all three disciplines-Folklore Studies, Cultural Studies, and Social History-are undergoing reflexive examination, which means the opening up of new opportunities for cross-disciplinary debate and co-operation. In closing, then, a note about some points of convergence, productive difference, and dialogue among our disciplines.

\section{$B H$}

Unlike Folklore Studies and Social History, Cultural Studies has been preoccupied with the emergent elements of contemporary cultural formations: new forms of hegemony, cultural inventiveness on ethnic boundaries, new ways of thinking among intellectuals. While this focus is "history" too, Cultural Studies has often been insufficiently concerned with the longer-term past of cultural forms and the ways they have changed their meanings and use with social or geographical location. This means that Cultural Studies scholars need to acquire a longer memory from colleagues in both Social History and Folklore-including a longer memory about their own and adjacent disciplines. Even a future-oriented approach requires a longer memory, not least to uncover the unrealized possibilities and unfinished stories of the past.

While some Cultural Studies scholars are seeking to rehistoricize their approach, Folklore Studies in the Netherlands (recently renamed Dutch Ethnology, like departments of European Ethnology in Germany and elsewhere) is now very much orienting toward the present, especially through an interest in contemporary representations of the past in public folklore and other forms of heritage. Projects that cut right across all our fields include Raphael Samuel's trilogy Patriotism (1989) and his Theatres of Memory (1994) in Britain, Nora's Les lieux de mémoire (1984-92) in France, the "Identity Factory" of Gerard Rooijakkers and others in the Netherlands, ${ }^{11}$ the German pioneerwork of Lutz Niethammer and Alexander von Plato on Lifehistory and Social Culture in the Ruhr (1983-85), and many other discussions on remembering and representing a past-collective and personal, local, national, or transnational.

Possibilities for cross-disciplinary learning in terms of method also exist. Cultural Studies has often been a more theoretically led field than either Social History or Folklore Studies. While history and folklore can learn from cultural theory, Cultural Studies may be inspired and deepened by the empirical engagements that folklore and history may bring. As early as 1968, in a subtle article on the differences and connections between American anthropologists and European ethnographers, Tamás Hofer argued that the "books of ethnographers may be compared to icebergs: besides the facts on the printed page, there is a lot which does not emerge above the level of the water. In America, on the contrary, the glittering hypotheses and theories are on the top and most of the factual material is forced below the water level" (1968:314). This difference involves intellectual styles and levels of abstraction more than some essential difference of value or truth. In all disciplines, the best work perhaps moves between these levels, making both theoretical assumptions and their referents in observation or narrative equally visible. 
Other differences too are productive if approached as complementary in some sense. All three disciplines have focused on the popular and often on marginal groups. Cultural Studies has been more involved in analyzing public representations, such as modern media forms and audiences, while Social History focused on the "lived experiences" of individuals and groups. Yet these two aspects of cultural processes need to be analyzed together. Certainly it is doubtful if such value-laden dichotomies as authentic/mediated can be sustained, except analytically, under modern cultural conditions. Local, everyday life or "lived" forms of culture and cultural practice are today always framed and interpenetrated by forms of public communication that are often global in their reach (e.g., Ang 1982). So the possibilities of more cross-disciplinary dialogue seem promising. Our story suggests, however, that this dialogue will happen only if we share common issues and also some basic agreements (or agreements to differ) about political and ethical orientations.

In many ways the "political epistemologies" that have emerged from Marxist, feminist, and other critical debates-and from everyday intellectual practices (often outside the academy) - in the last twenty years are relevant to the dialogue across disciplines and national traditions (e.g., Gadamer 1989; Haraway 1991). Communication and dialogue themselves are strongly stressed in these debates, so that thoughtfulness and a "self-reflexive" explicitness about our assumptions, methodologies, and social positioning are seen as ways to enable dialogue across social positions and intellectual traditions. The stress on dialogue includes the "Self:Other" relations that are constructed between researchers and researched and also those between researchers themselves. Indeed, in the most complex appraisals of "I:Thou" relations in research, spatial, temporal, and cultural dimensions of difference are taken into account along with social differences of power. Dialogue and reflexivity are closely linked, since it is only when the self is risked that dialogue is really possible and becomes exciting. A further emphasis relates to accountability, not so much accountability to governments or to large-scale business (the commonest demands on academics today), but to the "subjects" of our research, whether in the past or in the present. This accountability involves an engagement different from romantic identification or "empathy." It recognizes that we cannot fully "know" the other, but we can listen to and learn from what the other has to say (cf. Portelli 1991:96-197).
As we read our way into debates about Folklore Studies, we do indeed find many of our own preoccupations echoed or usefully challenged. For instance, we find resonances in Regina Bendix's explorations of the relationship between power and scholarly verifications of "authenticity" (1997) and in Barbara Kirshenblatt-Gimblett's assertion that all our disciplines actively produce a version of culture in order to study it (1998).

\section{$R J$}

Finally, there are some issues of power, possession, and "territory." Like free trade in economic goods, "the free flow of ideas" tends to favor powerful positions in the world economy of the academy, measured especially in terms of access, resources, language, academic styles, and capacities of presenting oneself. We are far from arguing for a dismantling of the borders of national or disciplinary differences. Across these differences, however, as we think our histories have shown, the development of disciplines or approaches does require an opening up and sharing, not a retreat in which our own "peculiarities" (national, disciplinary, perspectival) are "kept to ourselves." If, as contemporary critics of science argue, all knowledges are "situated" and "partial," then checking in with the others is all the more important.

\section{Meertens Institute}

Amsterdam

University of Nottingham-Trent

\section{Notes}

1. For an account of this debate, see Samuel 1981, especially the section on "Culturalism: Debates around the Poverty of Theory," pages 375-408.

2. The results were made accessible through a well-illustrated book and an exhibition; see Henkes and Oosterhof 1985.

3. See Henkes 1995. For publications on this research in English, see Henkes 1990, 1993, 2001.

4. Apart from his early-modern work, Willem Frijhoff too has been explicitly reflecting on the relation between Folklore Studies and Cultural Sciences in the Netherlands. See Frijhoff 1997; also Roodenburg, this volume.

5. See Richardson 1994. Thompson's engagements with folklore and folklorists 
Wh best tuced in his 1991 Customs in Common. Thompson himself stressed-as we do:me importance of political divergences in the relative neglect of folk loire studies in England (Thompson 1994:205-06).

6. "Cultural Brokerage: Forms of Intellectual Practice in Society"-a special double issue of the Journal of Folklore Research (36/2-3) published in 1999 and edited by Regina Bendix and Gisela Welz-brings together essays and responses from German and American scholars about the historical and future trajectories of public sector work, and about moves to theorize practice, create disciplinary boundaries, and establish qualifications for arbiters of culture.

7. Jaarboek voor de geschiedenis van het socialisme en de arbeidersbeweging in Nederland appeared from 1976-81. Its founding editors were Jacques Giele, Ger Harmsen Albert Mellink, Joyce Outshoorn, and Bob Reinalda. It was continued as the Bulletin Nederlandse Arbeidersbeweging, a "grey" magazine published outside the official publishers' circuit until December 1995.

8. Freely rendered from Ger Harmsen and Bob Reinalda's For the Liberation of Labor: A Short History of the Dutch Labor Movement (1975), which during the seventies obtained the status of a reference book within circles of radical sociatist historians.

9. See, for example, the collections of papers presented during two national conferences of Geschiedenis en Bevrijding (History and Liberation), the first organized at the Free University of Amsterdam in 1979 and the second at the University of Groningen in 1981, as well as the volumes of the historical magazine Groniek from 1979-81. The students from the University of Utrecht (in 1978) and Groningen (in 1983) started their "history workshops" (Geschiedeniswinkels) to help individuals and groups write their own history.

10. For instance, in his 1979 article "De taal van de wetenschap" ("The Language of Science"), Voskuil presents a clever analysis of the ways that politics, culture, and academic knowledge are interwoven. In this review he discusses Volkskunde. Eine Einführung (Wiegelmann, Zender, and Heilfurth 1977) against the background of generational differences and individual involvements that affect the perspectives of the three authors.

11. The Identiteitsfabriek Zuid-Oost (IDZO) is a project in the region of southeast Brabant that aims to develop an infrastructure of cultural elements by which the visitors can be amused, confirmed, and confronted by "safe" and "risky" stories at different sites in the region. See also <http:/ /www.idzo.nl $>$.

\section{References Cited}

Ang, Ien

1982 Het geval Dallas. Populaire kultuur, ideologie en plezier. Amsterdam: SUA. In English: Watching Dallas: Soap Opera and the Melodramatic Imagination. London: Methuen, 1985

Armstrong, Frankie, and Brian Pearson

1979 "Some Reflections on the English Folk Revival." History Workshop Journal 7 (spring):95-100
Bendix, Regina

1997 In Search of Authenticity: The Formation of Folklore Studies. Wisconsin: University of Wisconsin Press.

Burke, Peter

1981 "The 'Discovery' of Popular Culture." In People's History and Socialist Theory, ed. Raphael Samuel, 216-26. Amsterdam: Van Gennep.

Centre for Contemporary Cultural Studies

1982 Making Histories: Studies in History-writing and Politics. Ed. Richard Johnson. London: Hutchinson.

Centre for Contemporary Cultural Studies Education Group

1981 UnpopularEducation: Schooling and Social Democracy in England since 1944. London: Hutchinson.

Chambers, Iain, and Lidia Curti

1996 The Post-Colonial Question: Common Skies, Divided Horizons. London: Routledge.

Davin, Anna

2000 "The Only Problem Was Time." History Workshop Journal 50 (autumn): $239-45$.

Dekker, Ton

2000 "Ideologie en volkscultuur ontkoppeld: een geschiedenis van de Nederlandse volkskunde." In Volkscultuur. Een inleiding in de Nederlandse etnologie, ed. Ton Dekker, Herman Roodenburg, and Gerard Rooijakkers, 13-65. Nijmegen: SUN.

Dorson, Richard M.

1965 "Folklore and Folklife Studies in Great Britain and Ireland." Journal of the Folklore Institute 2:239-43.

1968 The British Folklorists: A History. London: Routledge and Kegan Paul.

Epstein, Debbie, and Richard Johnson

1998 Schooling Sexualities. Buckingham: Open University Press.

Foucault, Michel

1980 Power/Knowledge: Selected Interviews and Other Writings 1972-1977. Ed. Colin Gordon, trans. Colin Gordon et al. Hemel Hempstead: Harvester Wheatsheaf.

Frijhoff, W. Th. M.

1997 "Volkskunde en cultuurwetenschap: the ups en downs van een dialoog." In Mededelingen van de Afdeling van de Knaw 60/3:89-143.

Gadamer, Hans-Georg

1989 Truth and Method. London: Sheed and Ward.

Gilroy, Paul

1987 There Ain't No Black in the Union Jack. London: Hutchinson.

Hall, Stuart

1981 "In Defence of Theory." In People's History and Socialist Theory, ed. Raphael Samuel, 378-85. Amsterdam: Van Gennep.

1999-2000 "Whose Heritage? Un-settling 'The Heritage,' Re-imagining the Postnation." Third Text: Critical Perspectives on Contemporary Art and Culture 49 (winter):3-14. 
Hall, Stuart, et al.

1978 Policing the Crisis: Muggings, the State, Law, and Order. London: Macmillan.

Haraway, Donna

1991 "Situated Knowledge: The Science Question in Feminism and the Privilege of Partial Perspective." In Simians, Cyborgs, and Women: The Reinvention of Nature, 183-201. London: Free Association Books.

Harmsen, Ger, and Bob Reinalda

1975 Voor de Beorijding van de Arbeid.Beknopte geschiedenis van de Nederlandse vakbeweging. Nijmegen: Socialistische Uitgeverij Nijmegen.

Henkes, Barbara

1980 Verdoemden in honger'sfeer. Werkloosheid en kriminalteit in de jaren dertig. Groningen: Instituut voor Kriminologie.

1990 "Changing Images of German Maids during the Inter-war Period in the Netherlands: From Trusted Help to Traitors in the Nest." In The Myths We Live By, ed. Paul Thomson and Raphael Samuel, 225-38. London: Routledge.

1993 'German Maids in Prosperous 'Guldenland' (Guilderland) and the Land of Moral Threat: Nation Images and National Identity during the Interbellum Period." In Images of the Nation: Different Meanings of Dutchness, 1870-1940, ed. Annemieke Galema, Barbara Henkes, and Henk te Velde, 133-58. Amsterdam: Rodopi.

1995 Heimat in Holland. Duitse dienstmeisjes 1920-1950. Amsterdam: Babylon/ De Geus. In German: Heimat in Holland. Deutsche Dienstmädchen 1920 1950. Straelen: Straelener manuskripte Verlag, 1998.

2000 "Voor Volk en Vaderland. Over de omgang met wetenschap en politiek in de volkskunde." In Volkseigen. Ras, cultuur en wetenschap in Nederland 1900-1950, ed. Martijn Eickhoff, Barbara Henkes, and Frank van Vree, 62-94. Amsterdam: Walburg Press and Nederlands Instituut Voor Oorlogsdocumentatie.

2001 "Maids on the Move: Images of Femininity and European Women's Labour Migration during the Interwar Years." In Women, Gender and Labour Migration: Historical and Global Perspectives, ed. Pamela Sharpe, 224-43. London: Routledge.

Henkes, Barbara, and Hanneke Oosterhof

1985 Kaatje ben je boven. Leven en werken van Nederlandse dienstboden, 1900-1940. Nijmegen: SUN.

Hofer, Tamás

1968 "Comparative Notes on the Professional Personality of the Disciplines." Current Anthropology 9/4:311-15.

Holst-van der Schalk, H. Roland

[1902, 1932] 1977 Kapitaal en arbeid in Nederland. Bijdrage tot de economische geschiedenis der 19de eeuw. 2 vols. Nijmegen: Socialistsiche Uitgeverij
Nijmegen.

Howkins, Alun, and Ian Dyck

1987 “'The Times' Alteration': Popular Ballads, Rural Radicalism and William Cobbett." History Workshop Journal 23 (spring):20-38.
Johnson, Richard

1970 "Educational Policy and Social Control in Early Victorian England." Past and Present 49:96-119.

1976 "'Really Useful Knowledge': Radical Education and Working-class Culture 1790-1848." In Working-class Culture: Studies in History and Theory, ed. John Clarke, Chas Critcher, and Richard Johnson, 75-102. London: Hutchinson.

1981 "Against Absolutism." In People's History and Socialist Theory, ed. Raphael Samuel, 386-95. Amsterdam: Van Gennep.

1997 "Teaching Without Guarantees: Cultural Studies, Pedagogy and Identity." In A Question of Discipline: Pedagogy, Power and the Teaching of Cultural Studies, ed. Joyce E. Canaan and Debbie Epstein, 42-73. Boulder, Colo.: Westview Press.

2000 "Academics under Pressure: Power and Paradigm in Two Historical Periods." In Volkseigen. Ras, cultuur en wetenschap in Nederland 1900-1950, ed. Martijn Eickhoff, Barbara Henkes, and Frank van Vree, 190-212. Amsterdam: Walburg Press and Nederlands Instituut Voor Oorlogsdocumentatie.

Kirshenblatt-Gimblett, Barbara

1988 "Mistaken Dichotomies." Journal of American Folklore 101:140-55.

1998 "Folklore's Crisis." Journal of American Folklore 111:281-327.

Lowenthal, David

1985 The Past Is a Foreign Country. Cambridge: Cambridge University Press.

Lutz, Helma, Anne Phoenix, and Nira Yuval-Davis, eds.

1995 Crossfires: Nationalism, Racism, and Gender in Europe. London: Pluto.

Morley, David, and Kuan-Hsing Chen, eds.

1996 Stuart Hall: Critical Dialogues in Cultural Studies. London: Routledge.

Newall, Venetia

1971 "Some Problems Relating to the Study of Folklore in England." Journal of American Folklore 84:328-32.

Niethammer, Lutz, and Alexander von Plato, eds.

1983-85 Lebensgeschichte und Sozialkultur im Ruhrgebiet 1930 bis 1960. 3 vols.: Faschismuserfahrungen im Ruhrgebiet, Nachkriegserfahrungen im Ruhrgebied, and Aufder Suche nach der Erfaherung des volkes in nachfascistischen Ländern. Berlin: Dietz Verlag.

Nora, Pierre, ed.

1984-92 Les lieux de mémoire. 7 vols. Paris: Gallimard.

Passerini, Luisa, Patrick Friedenson, and Lutz Niethammer

1998 "International Reverberations: Remembering Raphael." History Workshop Journal 45 (spring) :246-60.

Portelli, Alessandro

1991 The Death of Luigi Trastulli and Other Stories: Form and Meaning in Oral History. Albany: State University of New York Press.

Richardson, Ruth

1994 "Obituary of E. P. Thompson." Folklore (London) 105:97-98. 
Samuel, Raphael

1989 Patriotism. 3 vols.: History and Politics, Minorities and Outsiders, and $\mathrm{Na}$ tional Fictions. London: Routledge.

Samuel, Raphael, ed.

1981 People's History and Socialist Theory. Amsterdam: Van Gennep.

1994 Theatres of Memory: Past and Present in Contemporary Culture. Vol. 1. London and New York: Verso.

Samuel, Raphael, and Paul Thompson, eds.

1990 The Myths We Live By. London: Routledge.

Scott, Joan Wallach

1988 "Gender: A Useful Category of Historical Analysis." In Gender and the Politics of History. New York: Columbia Press. First published in American Historical Review 91/5:28-50, 1986.

Steele, Tom

1997 The Emergence of Cultural Studies 1945-65: Cultural Studies, Adult Education, and The English Question. London: Lawrence and Wishart.

Storey, John, ed.

1996 What is Cultural Studies? A Reader. London: Edward Arnold.

Thompson, E. P.

1963 The Making of the English Working Class. London: Gollanz.

1991 Customs in Common. London: Penguin.

1994 Persons and Polemics: Historical Essays. London: Merlin Press.

Thompson, E. P., ed.

1970 Warwick University Ltd.: History, Management and the University. Harmondsworth: Penguin.

Voskuil, Han

1979 "De taal van de wetenschap." Volkskundig Bulletin 5:21-43.

1996-2000 Het Bureau. 7 vols. Amsterdam: Van Oorschot.

Wiegelmann, Günter, Matthias Zender, and Gerhard Heilfurth

1977 Volkskunde. Eine Einführung. Berlin: Erich Schmidt Verlag.

Yuval-Davis, Nira, and Floya Anthias, eds.

1989 Women-Nation-State. London: Macmillan. 